\title{
Yenilenebilir Enerji Kaynağı Kullanımının Çevre Kirliliği Üzerindeki Etkisinin Araştırılması: Sürekli Dalgacık Uyumu Modeli Yaklaşımı ${ }^{1}$
}

Investigation of the Effect of Renewable Energy Resources on the Environment Pollution: Continuous Wavelet Coherence Model Approach

\author{
Öğr. Gör. Dr. Sevda Kuşkaya² - Prof. Dr. Faik Bilgili³
}

Başvuru Tarihi: 15.10 .2018

Kabul Tarihi: 23.12.2019

Öz

Sera gazları, yeryüzü sıcaklı̆̆ı üzerinde doğrudan etkisi olan ve yoğunluğu aşırı arttığında küresel ısınmaya yol açan atmosfer bileşenleridir. Artan enerji ihtiyacı ve beraberinde getirdiği küresel ısınma hem gelişmiş hem de gelişmekte olan ülkelerin ortak sorunu haline gelmiştir. Bu nedenle, küresel ısınmanın kontrol altına alınmasında yenilenebilir enerji kaynakları kullanımının, karbondioksit $\left(\mathrm{CO}_{2}\right)$ emisyonu üzerindeki etkisinin araştırılması önemli bir araştırma konusudur.

Ülkelerin $\mathrm{CO}_{2}$ emisyonları dikkate alındığında, Amerika Birleşik Devletleri (ABD) ilk sıralarda yer almaktadır. Bu duruma ek olarak hem enerji verilerine erişilebilirlik hem de kullanılan enerji değişkenlerinin yüksek frekansa sahip olması nedeniyle analiz için ABD tercih edilmiştir. Dalgacık uyumu (wavelet coherence) yöntemlerinden birisi olan Morlet dalgacık uyumu modelinin kullanıldığ çalışmada, 1989:1-2017:8 dönemi dikkate alınmıştır. ABD’nin biyoyakıt tüketimi, toplam biyokütle enerji tüketimi, odun enerji tüketimi, hidroelektrik enerji tüketimi, sanayi üretim endeksi, toplam fosil yakıt tüketimi, nükleer enerji tüketimi ve toplam enerji ile ilişkili karbon dioksit emisyonu değişken olarak modele dahil edilmiştir. Analiz neticesinde; biyoyakıt ve toplam biyokütle enerji kullanımı ile $\mathrm{CO}_{2}$ emisyonu arasındaki ilişkinin negatif korelasyona sahip olduğu faz aralıkları belirlenmiştir. Böylece, yenilenebilir enerji kaynağı kullanımının $\mathrm{CO}_{2}$ emisyonuna öncülük ederek, emisyonu azalttığı dönemlerin olduğu sonucuna ulaşılmıştır.

Anahtar Kelimeler: Çevre Kirliliği, $\mathrm{CO}_{2}$ Emisyonları, Dalgacık Uyumu, Enerji Tüketimi

\footnotetext{
1 Bu çalışma, birinci yazarın ikinci yazar danışmanlığında hazırladığı "Küresel Isınmanın Kontrol Altına Alınmasında Takip Edilen Enerji Politikalarının Etkinliği: Bir Sürekli Dalgacık Uyumu Modeli Yaklaşımı” başlıklı doktora tezinden türetilmiştir.

2 Erciyes Üniversitesi, Adalet MYO, sevdakuskaya@gmail.com, ORCID: 0000-0003-4527-5713

3 Erciyes Üniversitesi İ̈BF, fbilgili@erciyes.edu.tr, ORCID: 0000-0003-4138-6897
} 


\section{Abstract}

Greenhouse gases are atmospheric components that directly affect the earth's temperature and cause global warming when the intensity increases excessively. Increasing the energy demand and global warming has become the common problem of both developed and developing countries. For this reason, it is important to investigate the effect of the usage of renewable energy sources on carbon dioxide $\left(\mathrm{CO}_{2}\right)$ emissions to control global warming.

The United States (USA) is in the first place when countries' $\mathrm{CO}_{2}$ emissions are taken into account. In addition to this, the USA has been preferred for analysis because of both its accessibility to energy data and the high frequency of energy used. As a method of analysis, Morlet wavelet analysis, which is one of the wavelet adaptation methods, has been preferred. As variables in the article; US biofuel consumption, total biomass energy consumption, wood energy consumption, hydropower consumption, industrial production index, total fossil fuel consumption, and finally total carbon dioxide emissions were used. As a result of the analysis; periods in which there is a negative correlation between the use of biofuel, and total biomass energy use, and $\mathrm{CO}_{2}$ emissions have been phase difference have been determined. Thus, it has been founded that the usage of the renewable energy source reduces the emission by leading to the $\mathrm{CO}_{2}$ emission of usage.

Keywords: Environment Pollution, $\mathrm{CO}_{2}$ Emissions, Wavelet Coherence, Energy Consumption

\section{Giriş}

Enerji, ülkelerin ekonomik ve üretim faaliyetleri açısından hayati öneme sahip bir kaynaktır. Bir sistemin kendisi dışında etkinlik üretme yeteneği (Kayfeci, 2011, s.2), şeklinde tanımlanan enerjiye olan talep her geçen gün artmaktadır. Bunun en önemli nedenleri arasında artan nüfus ve nüfusun ihtiyaçlarını karşılamak amacıyla artan üretim faaliyetleri gelmektedir. Üretimin temel bileşenlerinden biri olan enerji, kaynak bakımından yenilenemeyen enerji (geleneksel enerji) ve alternatif enerji (yenilenebilen enerji) olmak üzere iki gruba ayrılmaktadır. Yenilenemeyen enerji kaynağı, salınımı insan müdahalesine bağlı olan ve statik enerji depolarından elde edilebilen enerjidir. Bu enerji, pratikte izole edilmiş bir potansiyele sahiptir ve enerji akımını başlatmak için bir dış etkiye ihtiyaç duymaktadır (Acaroğlu, 2007, s.2). Yenilenemeyen enerji kaynakları; doğal gaz, kömür, petrol ve nükleer (uranyum, toryum) enerji şeklinde sıralanabilmektedir. Bu kaynaklar fosil enerji kaynakları olarak da adlandırmaktadır. Yenilenilenebilir enerji ise; doğal çevreden sürekli veya tekrarlamalı olarak devam eden kaynaktan elde edilebilen enerji türüdür. En yaygın olanı, 24 saat enerji sağlayan güneştir. $\mathrm{Bu}$ enerjilerin temel özelliği, geleneksel enerji kaynaklarının aksine herhangi bir dış etkene gerek duyulmaksızın çevrede doğal halde bulunmalarıdır. Başka bir ifadeyle, enerji akımını başlatmak için herhangi bir dış etkiye ihtiyaç duyulmamaktadır. Alternatif enerjiler; güneş enerjisi, rüzgâr enerjisi, gel-git enerjisi, hidroelektrik enerji, jeotermal enerji ve biyokütle enerjisinden oluşmaktadır (Irps, 2009, s. 202; Acaroğlu, 2007, s. 2).

Yenilenebilir enerji kaynaklarından biri olan biyokütle, biyolojik kökenli enerji kaynaklarını tanımlamak için kullanılan bir ifadedir. Bu terim; ağaçlar, ekinler ve yosunların yanı sıra tarım 
ve orman atıklarını da içeren geniş bir kavramdır. Tüketim açısından biyokütle enerjisi; 1sınma, elektrik üretimi ya da taşıtlarda yakıt olmak üzere birçok alanda kullanılmaktadır (WES, 2015, s. 241). Ayrıca biyokütle, orijinal formunda yakıt olarak kullanılabilmesinin yanı sıra farklı türde katı, sıvı veya gaz biyoyakıtlara rafine edilebilmektedir. Biyokütle enerjisinden isı veya elektrik enerjisi üretilmesi durumuna biyoyakıt denilmektedir. Biyoyakıtlar; tarım, ormancılık, belediye atıkları, şeker, hububat ve bitkisel yağ gibi ürünlerden üretilebilmektedirler (Worldenergy, 2018). Biyokütle ve biyoyakıt gibi biyolojik kökenli enerjilerin (biyoenerji) kullanımının sağladığı başlıca avantajlar aşağıda yer almaktadır (Bhattacharjee, 2012, s.13):

- Biyoenerji birçok alandan elde edilebilmektedir.

- Biyoenerji, atıklardan ve diğer organik materyallerden üretilmektedir. Bu durum hem çevre hem de ekonomi için maliyet tasarrufu sağlamaktadır.

- Eğer geniş miktarda biyoenerji kullanılırsa, fosil yakıt ithalatı azaltılarak ulusal ekonominin olumlu etkilenmesi sağlanabilmektedir.

- Özellikle bitkilerin biyokütle üretimi için kullanılması, $\mathrm{CO}_{2}$ emisyon miktarını azaltarak çevreye pozitif katkı sağlamaktadır.

Bahsedilen avantajlar çerçevesinde çalışmada yenilenebilir enerji kaynakları olarak biyokütle ve biyoyakıt enerjileri ele alınmıştır. Bu doğrultuda çalışma dört bölümden oluşmuştur. İlk bölümde fosil enerji kullanımından kaynaklanan çevre sorunlarına yer verilmiştir. Bu başlık altında; küresel ısınma, sera gazı ve $\mathrm{CO}_{2}$ emisyonu kavramlarına değinilmiştir. Devam eden bölümde yenilenebilir enerji kaynağı kullanımının sera gazı emisyonu üzerinde ki etkisini araştıran ampirik çalışmalar değerlendirilmiştir. Üçüncü bölüm ekonometrik analiz ve bulgulardan oluşmaktadır. İlgili bölüm, veri seti ve temel istatistiki özellikleri, analiz yöntemi ve analiz bulguları olmak üzere üç alt başlıktan oluşmaktadır. Son bölümde ise analiz sonuçları yer almıştır.

\section{Fosil Enerji Kullanımından Kaynaklanan Çevre Sorunları}

Fosil yakıt kullanımı kaynaklı çevre sorunlarının başında küresel ısınma ve iklim değişikliği gelmektedir. İklim değişikliği hem ülke ekonomilerini hem de insan yaşamını etkileyen önemli bir çevre sorunudur. Küresel ısınma ve dolayısıyla iklim değișikliği, doğal kaynakları yok eden bir süreç olmasından dolayı, günümüz ve gelecekteki nesillerin ihtiyaçlarının karşılanması durumunu riske atmaktadır. Küresel ısınma teknik olarak, dünyanın atmosferinde meydana gelen, ortalama sıcaklıktaki artış olarak tanımlanmaktadır (Sorensen, 2014, s.1). Bu sıcaklık artışına neden olan atmosferin yapısında bulunan bazı gazlar vardır. Bu gazlar, sera gazları olarak adlandırılır. Sera gazları hem doğal hem de insan kaynaklı (antropojenik) oluşan atmosfer bileşenleridir. Bu gazlar; dünya yüzeyi, atmosfer ve bulutlar tarafından yayılan yeryüzüne ait radyasyon, 1şık dizisi içindeki özel dalga boylarına sahip olan radyasyonu emer ve tekrar yansitırlar. $\mathrm{H}_{2} \mathrm{O}, \mathrm{CO}_{2}, \mathrm{~N}_{2} \mathrm{O}, \mathrm{CH}_{4}, \mathrm{O}_{3}$ dünyanın atmosferinde doğal olarak bulunan başlıca sera gazlarıdır (IPCC, 2013, 1455). $\mathrm{CO}_{2}, \mathrm{CH}_{4}$ ve $\mathrm{N}_{2} \mathrm{O}$ gibi sera gazları atmosferde doğal olarak oluşmalarına rağmen insan aktiviteleri, bu gazların atmosferdeki yoğunluklarını değiştirebilirler (EPA, 2015, ES2). Atmosferde doğal olarak bulunmayan insan aktiviteleri sonucu ortaya çıkan sera gazları da vardır. İnsanların üretim faaliyetleri sonucu ortaya çıkan sera gazlarının başında; hidrofluorokarbonlar $\left(\mathrm{HFC}_{\mathrm{s}}\right)$, perfluorokarbonlar $\left(\mathrm{PFC}_{\mathrm{s}}\right)$ ve kükürt heksafluorid $\left(\mathrm{SF}_{6}\right)$ yer almaktadır (IPCC, 2013, 1455). 
Sera gazları dünya yüzeyi, atmosfer ve bulutlar tarafından yayılan yeryüzüne ait radyasyon, ışık dizisi içindeki özel dalga boylarına sahip olan radyasyonu soğurur (absorbe eder) ve tekrar yansitırlar. Bu özellik sayesinde sera gazları hesaplanan küresel sıcaklığ $1-18^{\circ} \mathrm{C}$ 'den $+15^{\circ} \mathrm{C}$ ye yükselmesine neden olurlar. Meydana gelen bu isınma olayı, sera etkisi olarak adlandırılmaktadır (Mitchell, 1989, s.115). Sera etkisi sayesinde yeryüzü olması gerekenden 33 ${ }^{\circ} \mathrm{C}$ daha sıcaktır. $\mathrm{Bu}$ 1sı artışı, yeryüzünü canlıların yaşayabileceği ortam koşullarına ulaştırmaktadır. Ancak özellikle sanayi devrimi sonrasında meydana gelen sera gazlarının atmosferde yoğunluklarındaki aşırı artış, yeryüzüne yakın atmosfer tabakaları ile yeryüzü sıcaklığının yapay olarak daha fazla ısınmasına neden olmuştur. Bu yapay sıcaklık artışı küresel 1sınma olarak adlandırılmaktadır (Bayraç, 2011, s.232). Dünyanın yakın yüzeyinde sıcaklık artışı olarak tanımlanan küresel ısınma, geçmişte olan doğal etkilerin sonucu olarak ortaya çıabileceği gibi, insan kaynaklı sera gazı salınımındaki artış sonucunda da oluşabilmektedir (IEA, 2016). Birçok bilimsel araştırma, fosil yakıt kullanımının, dolayısıyla karbon emisyonlarının sera etkisi ve küresel ısınmanın en önemli nedeni olduğunu ortaya koymaktadır (Tuna, 2000, s.7). Bu nedenle çalışmada sera gazı emisyonu açısından $\mathrm{CO}_{2}$ emisyonu dikkate alınmıştır. Son yıllarda $\mathrm{CO}_{2}$ emisyonunu azaltmaya yönelik çalışmalar, gelişmiş ve gelişmekte olan ülkeler açısından önem kazanan bir konudur. Dolayısıyla çalışmada hem $\mathrm{CO}_{2}$ emisyonu bakımından dünyada Çin'den sonra 2. ülke olması (Europa, 2018) hem de enerji verilerine ulaşlabilirlik açısından Amerika Birleşik Devletleri (ABD)'nin durumu değerlendirilmiştir.

\section{Literatür Taraması}

Literatür özetinde yenilenebilir enerji kaynağı kullanımı ve sera gazı emisyon azaltımı ile ilgili ampirik çalışmalara yer verilmiştir.

Say ve Yücel (2006) Türkiye’nin enerji sektörünü, 1970-2002 dönemi için incelemişlerdir. Toplam enerji tüketimi, ekonomik büyüme ve nüfus artı̧ını kullanarak model oluşturmuşlardır. Ayrıca toplam enerji tüketimi ile toplam $\mathrm{CO}_{2}$ emisyonu arasındaki ilişkiyi de araştırmışlardır. Bunun için ise, regresyon analizi yöntemini tercih etmişlerdir. Neticede, Türkiye'de enerji tüketimi ve $\mathrm{CO}_{2}$ emisyonu arasinda güçlü bir ilişki olduğu sonucuna ulaşmışlardır. Ayrıca enerji tüketiminin GSYİH (Gayri Safi Yurtiçi Hasıla) üzerinde pozitif etki oluştururken, $\mathrm{CO}_{2}$ emisyonun da enerji tüketimi üzerinde pozitif etki yarattığını tespit etmişlerdir. Soytas vd. (2007) $\mathrm{CO}_{2}$ emisyonu, enerji tüketimi ve gelir değişkenlerini kullanarak, ABD'de 1960-2004 dönemi için enerji tüketiminin karbon emisyonu üzerindeki etkisini araştırmışlardır. Granger nedensellik analizi sonuçlarına göre; ABD'de gelir ile karbon emisyonu arasında uzun dönemde herhangi bir ilişkiye rastlanmaz iken, gelir ile enerji tüketimi arasında nedensellik ilişkisi tespit edilmiştir. Soytas ve Sari (2009) Türkiye için 1960-2000 yllları arasında $\mathrm{CO}_{2}$ emisyonu, enerji tüketimi ve ekonomik büyüme arasında uzun dönemli ilişkiyi Granger nedensellik analizi kullanarak araştırmışlardır. Analiz neticesinde; Türkiye'de karbon emisyonu, enerji tüketiminin Granger nedeni iken bu durumun tersinin geçerli olmadığını ifade etmişlerdir. Zhang ve Cheng (2009) Çin ekonomisi için 1960-2007 dönemine ait verileri kullanarak ekonomik büyüme, enerji tüketimi ve karbon emisyonu arasında bir ilişki olup olmadığını ve varsa bu ilişkinin yönünü tespit etmeye çalışmışlardır. Granger nedensellik modelinin kullanıldığı araştırmada, uzun dönemde enerji tüketiminden karbon emisyonuna 
doğru tek yönlü nedensellik olduğu sonucuna varılmıştır. Ayrıca GSYİH'dan enerji tüketimine doğru tek yönlü nedensellik olduğu da tespit edilmiştir. Jalil ve Mahmud (2009) 1975-2005 dönemini inceleyerek, Çin ekonomisi için Çevresel Kuznet Eğrisi (EKC)'nin geçerliliğini test etmişlerdir. EKC hipotezi çevresel koşulların bir göstergesi olarak; kişi başına $\mathrm{CO}_{2}$ emisyonu, enerji tüketimi, ekonomik büyüme ve diş ticaret değişkenleri kullanılarak ARDL modeli kapsamında incelenmiştir. Araştırmacılara göre; $\mathrm{CO}_{2}$ emisyonu, uzun dönemde gelir ve enerji tüketimi tarafından belirlenmektedir. Ekonomik büyüme ise, $\mathrm{CO}_{2}$ emisyonuna neden olmaktadır. Çin için $\mathrm{CO}_{2}$ emisyonu ve dış ticaret ilişkisi dikkate alındığında, dış ticaretin $\mathrm{CO}_{2}$ emisyonu üzerinde pozitif fakat istatistiki olarak anlamsız bir etkisi olduğu sonucuna ulaşmışlardır. Menyah ve Rufael (2010) ABD'de 1960-2007 dönemi için $\mathrm{CO}_{2}$ emisyonu, yenilenebilir ve nükleer enerji tüketimi ve reel GSYIH arasındaki nedensellik ilişkisini araştırmışlardır. Çalışmada, nükleer enerji tüketiminden $\mathrm{CO}_{2}$ emisyonuna doğru tek yönlü negatif ilişki belirlemişlerdir. Bu durum, nükleer enerji kullanımının $\mathrm{CO}_{2}$ emisyonunu azalttı̆̆ 1 anlamına gelmektedir. Buna karşın, yenilenebilir enerji kullanımı ve $\mathrm{CO}_{2}$ emisyonu arasında hiçbir nedensellik ilişkisine rastlamamışlardır. Sonuç olarak araştırmacılar, $\mathrm{ABD}$ 'de $\mathrm{CO}_{2}$ emisyonunu azaltmak için nükleer enerji tüketiminin artırılması gerektiğini önermişlerdir. Iwata vd. (2012) 1977-2003 yılları arasında elektrik üretiminde nükleer enerjinin rolünü dikkate alarak, 11 OECD ülkesinde $\mathrm{CO}_{2}$ emisyonu için EKC hipotezini araştırmışlardır. ARDL yönteminin tercih edildiği çalışmada, nükleer enerji kullanımının sadece bazı ülkelerde $\mathrm{CO}_{2}$ emisyonunu azalttığını belirlemişlerdir. Bilgili (2012) ABD ekonomisinde, 1990:1-2011:11 dönemi için biyokütle tüketiminin $\mathrm{CO}_{2}$ emisyonunu azaltıp azaltmayacağını araştırmıştır. Biyokütle enerji tüketimi, $\mathrm{CO}_{2}$ emisyonu ve fosil yakıt tüketiminin değişken olarak kullanıldığı çalışmada rejim değişimli eşbütünleşme analizi (cointegration analysis with regime shift) kullanılmıştır. Analiz neticesinde; fosil yakıt kullanımının $\mathrm{CO}_{2}$ emisyonunu pozitif yönde etkilerken, biyokütle kullanımının $\mathrm{CO}_{2}$ emisyonunu negatif yönde etkilediği belirlenmiştir. Saboori ve Sulaiman (2013) Güneydoğu Asya Ülkeleri Birliği (ASEAN)'nde 1971-2009 dönemi için $\mathrm{CO}_{2}$ emisyonu, enerji tüketimi ve ekonomik büyüme arasındaki eşbütünleşme ve nedensellik ilişkisini araştırmışlardır. Granger nedensellik, ARDL ve VECM modellerinin kullanıldığı çalışmada araştırmacılar, bütün ASEAN ülkelerinde enerji tüketimi ve $\mathrm{CO}_{2}$ emisyonu arasında karşılıklı Granger nedensellik olduğu sonucuna ulaşmışlardır. Yousefi vd. (2014) İran'ın batısında, şeker pancarı tarımsal ekosistemleri için enerji kullanımı ve sera gazı emisyonları $\left(\mathrm{CO}_{2}, \mathrm{~N}_{2} \mathrm{O} \text { ve } \mathrm{CH}_{4}\right)^{\prime}$ 'nın toplamlarını belirlemeye çalışmışlardır. 2012 yılı için 50 çiftçi ile yüz yüze anket yöntemi kullanılarak elde edilen verilerle göre, şeker pancarı çiftçiliğinin, toplam küresel ssınma potansiyelinin $\mathrm{CO}_{2}$ eşitliği açısından; \%27'sinin $\mathrm{CO}_{2}^{\prime}$ 'den, \%72'sinin $\mathrm{N}_{2} \mathrm{O}$ 'dan ve \%1'inin ise $\mathrm{CH}_{4}^{\prime}$ den kaynaklandığı sonucuna ulaşmışlardır. Baek (2015) tarafından 12 nükleer enerji üreten ülke için 1980-2009 döneminde nükleer enerji tüketiminin, $\mathrm{CO}_{2}$ emisyonu üzerindeki etkisini araştırılmıştır. $\mathrm{CO}_{2}$ emisyonu, nükleer enerji tüketimi ve gelirin değişken olarak tercih edilen çalışmada panel eşbütünleşme yöntemi kullanılmıştır. Analiz neticesinde hem nükleer enerji kullanımının hem de ekonomik büyümenin $\mathrm{CO}_{2}$ emisyonunu azaltma eğiliminde olduğu belirlenmiştir. Ayrıca çalışmada, nükleer enerji kullanımının çevre üzerinde zararlı etkiye sahip olduğu vurgulanmıştır. Bilgili vd. (2016) ABD için 1983:1-2015:2 dönemini incelemişlerdir. Çalışmada biyokütle tüketiminin, $\mathrm{CO}_{2}$ emisyonu üzerindeki etkisi araştırılmıştır. Değişken olarak; $\mathrm{CO}_{2}$ emisyonu, biyokütle 
tüketimi, kömür tüketimi, petrol tüketimi ve doğalgaz tüketimi tercih edilmiştir. Dalgacık analiz yönteminin kullanıldı̆̆ı makalede, biyokütle tüketiminin hem uzun hem de kısa dönemde $\mathrm{ABD}$ ’nin $\mathrm{CO}_{2}$ emisyonunu azaltmada etkili olduğu sonucuna ulaşmışlardır.

\section{Ekonometrik Analiz ve Bulgular}

\section{Veri Seti ve Temel İstatistiki Özellikleri}

$\mathrm{Bu}$ araştırmanın etkin bir şekilde yürütülebilmesi için ön koşul, ilgili değişkenlere ait gözlemlerin yüksek frekansa sahip olmaları gerekliliğidir. Bu amaç doğrultusunda, (i) yüksek frekansa sahip enerji üretim ve tüketim verilerine sahip olması, (ii) diğer takip edilebilecek yüksek frekanslı kontrol değişkenlere sahip olması, (iii) araştırma örneklemi olarak sera gazı emisyonu açısından Dünya'daki ikinci ülke konumunda olması, (iv) enerji verilerine de erişilebilirlik açısından, çalışmada Amerika Birleşik Devletleri'ne ait enerji verileri kullanılmıştır. Veri kısıtı dikkate alınarak analize, 1989:1-2017:8 dönemi dahil edilmiştir.

Çalışmanın bu bölümünde, ABD’ye ait değişkenlerin tanımlayıcı istatistikleri ve 1989:1-2017:8 zaman aralığında ki değişimleri ele alınmıştır. Sırasıyla şekillerde; ABD’nin biyoyakıt tüketimi, toplam biyokütle enerjisi tüketimi, odun enerjisi tüketimi, hidroelektrik enerjisi tüketimi, sanayi üretim endeksi, toplam fosil yakıt tüketimi, nükleer enerji tüketimi ve son olarak da toplam karbondioksit emisyonuna ait trend grafikleri ile bu değişkenlerin denklemlerine yer verilmiştir. Denklemlerle birlikte anlamlılık katsayı olarak ifade edilen $\mathrm{R}^{2}$ değerleri de yer almıştır. Daha sonra ABD enerji kaynaklarına ait özet tanımlayıcı istatistikler değerlendirilmiştir.

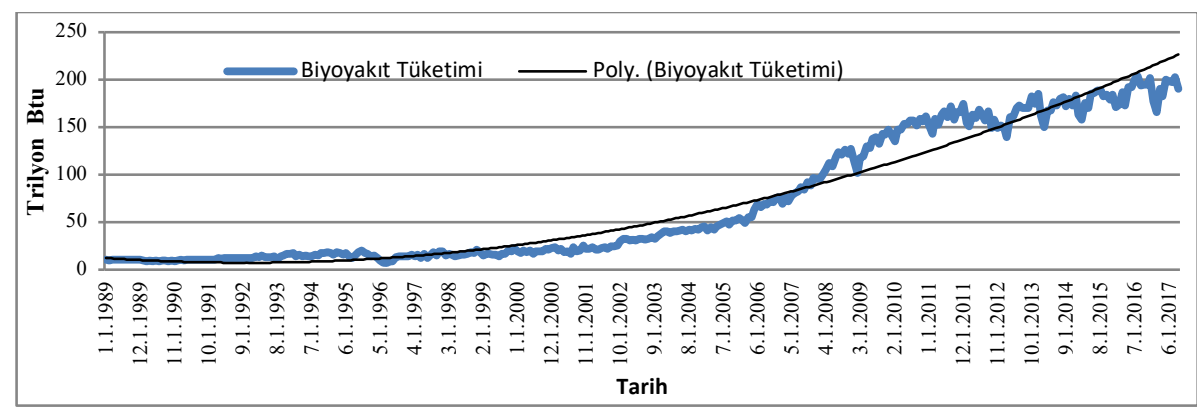

Şekil 1. ABD’nin Biyoyakıt Tüketimine Ait Trend Grafĭ̆gi (1989:1-2017:8)

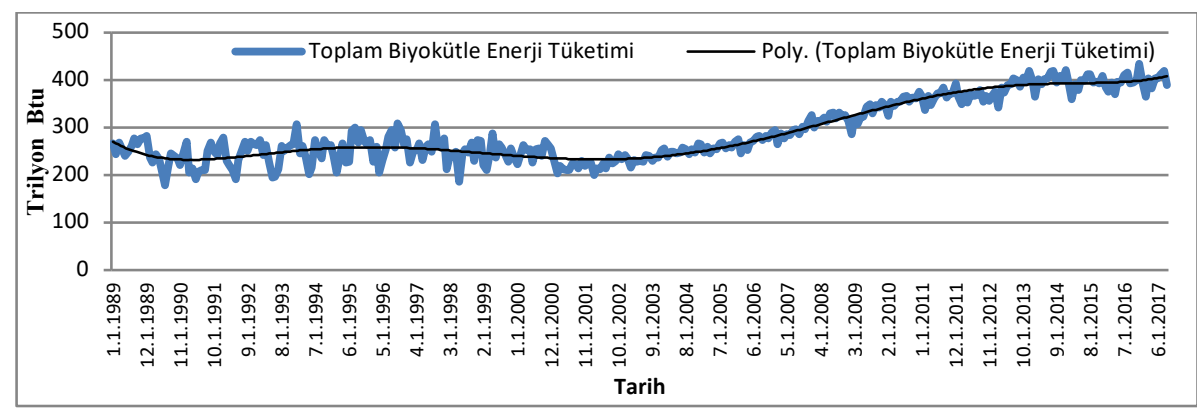

Şekil 2. ABD’nin Biyokütle Enerjisi Tüketimine Ait Trend Grafiği (1989:1-2017:8) 


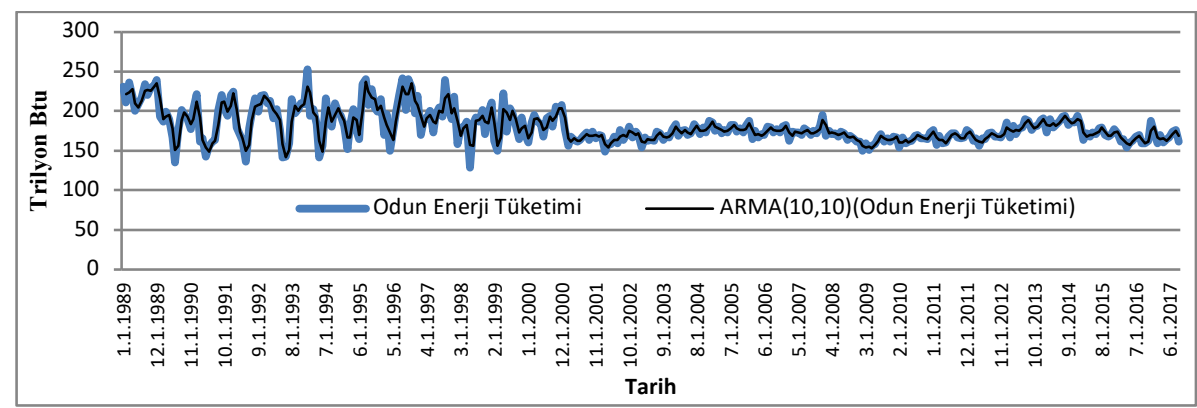

Şekil 3. ABD’nin Odun Enerjisi Tüketimine Ait Trend Grafiği (1989:1-2017:8)

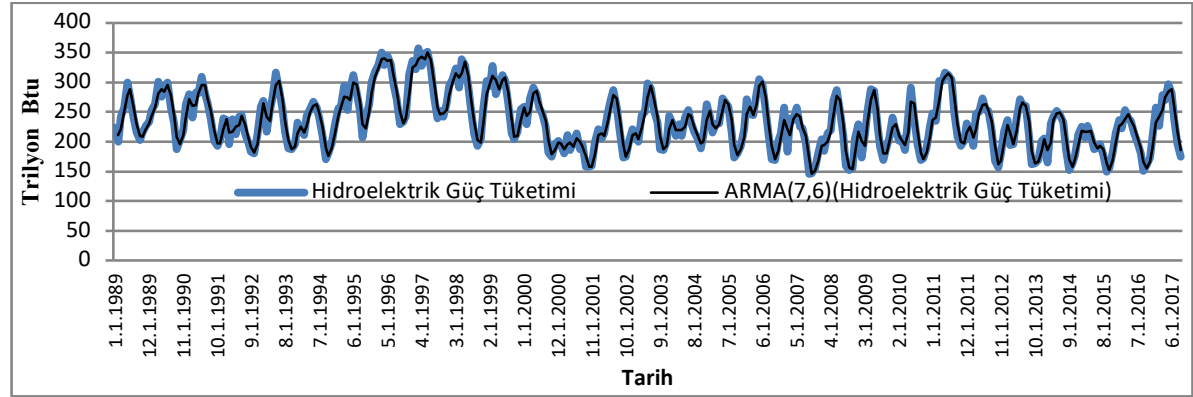

Şekil 4. ABD’nin Hidroelektrik Güç Tüketimine Ait Trend Grafiği (1989:1-2017:8)

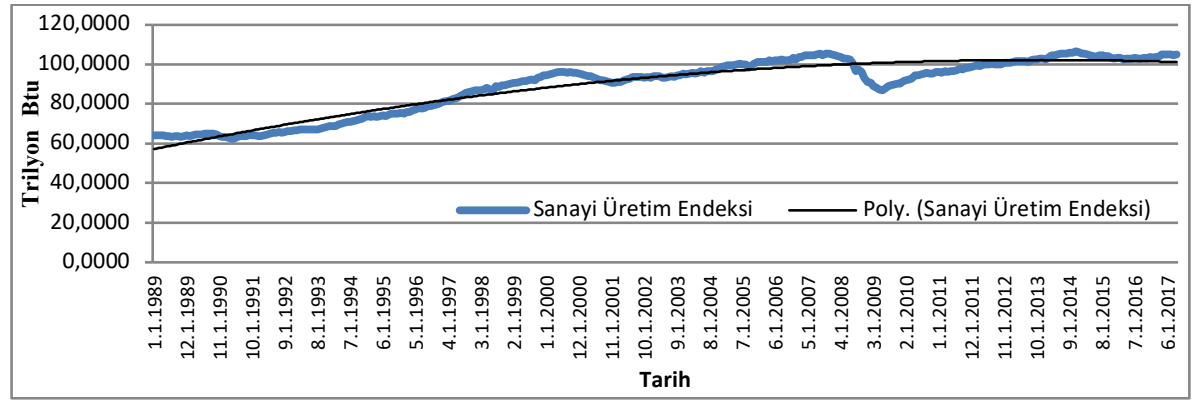

Şekil 5. ABD’nin Sanayi Üretim Endeksine Ait Trend Grafiği (1989:1-2017:8)

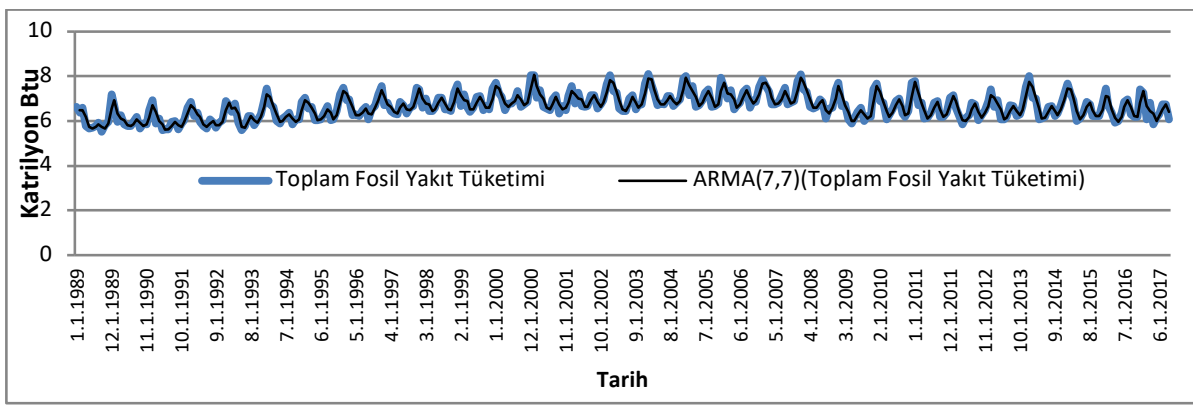

Şekil 6. ABD’nin Toplam Fosil Yakıt Tüketimine Ait Trend Grafiği (1989:1-2017:8) 


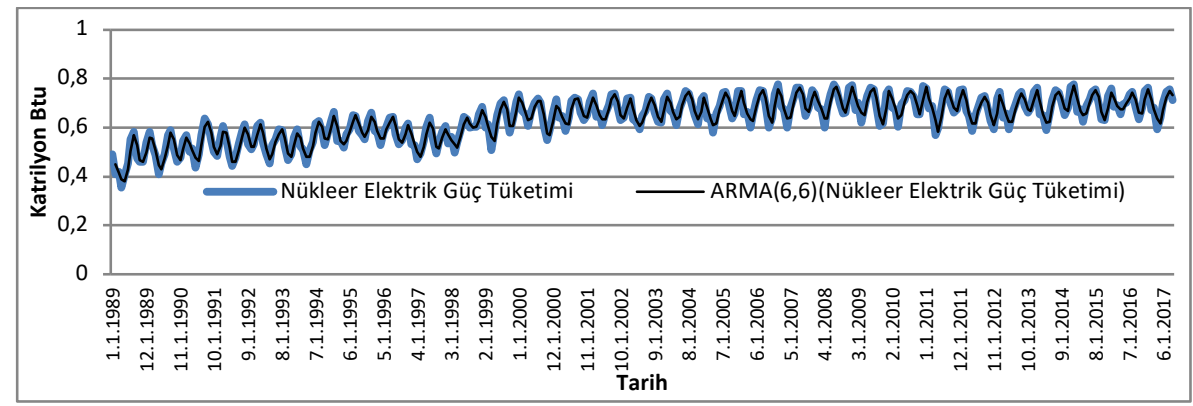

Şekil 7. ABD’nin Toplam Nükleer Elektrik Güç Tüketimine Ait Trend Grafiği

(1989:1-2017:8)

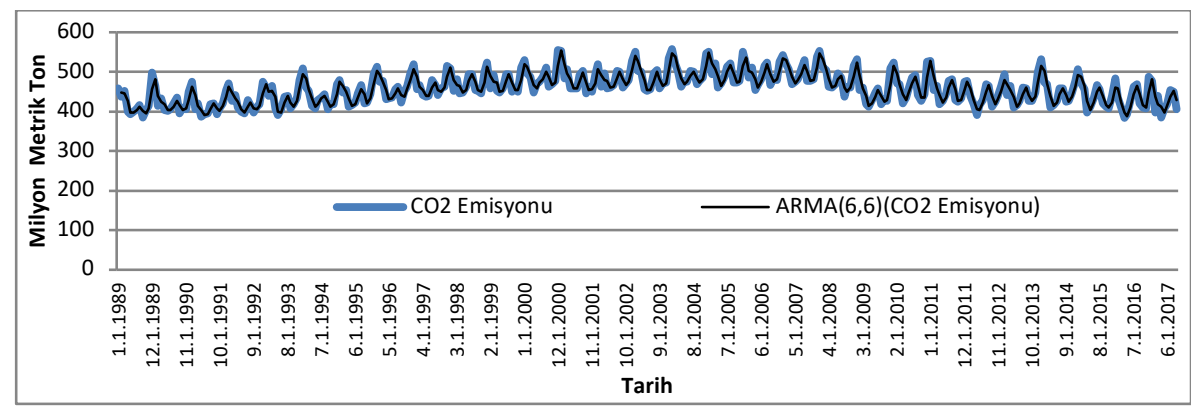

Şekil 8. ABD’nin Toplam Karbon Dioksit Emisyonuna Ait Trend Grafiği (1989:1-2017:8)

Şekil 1'den Şekil 8'e kadar sırasıyla biyoyakıt, biyokütle, odun, hidroelektrik, sanayi üretim endeksi, toplam fosil yakıt tüketimi, nükleer elektrik güç tüketimi ve toplam karbon dioksit emisyonuna ait çizgi grafikleri ve değişkenlere ait trendler yer almaktadır. Değişkenlere ait trend denklemlerine ve anlamlılık katsayı olarak ifade edilen $\mathrm{R}^{2}$ değerlerine Tablo 1'de yer verilmiştir.

Tablo 1. ABD’nin Enerji Kaynaklarına Ait Trend Denklemleri ve Anlamlılı Katsayıları

\begin{tabular}{|c|c|c|}
\hline Değișkenler & $\mathbf{R}^{2}$ & Denklem $^{4}$ \\
\hline $\begin{array}{l}\text { Biyoyakıt Enerji } \\
\text { Tüketimi }\end{array}$ & 0,950 & $y=3 E-06 x 2-0,1791 x+3040,8$ \\
\hline $\begin{array}{c}\text { Toplam } \\
\begin{array}{c}\text { Biyokütle Enerji } \\
\text { Tüketimi }\end{array}\end{array}$ & 0,911 & $y=2 E-20 x 6-5 E-15 x 5+5 E-10 x 4-2 E-05 x 3+0,7038 x 2-10598 x+7 E+07$ \\
\hline $\begin{array}{l}\text { Odun Enerji } \\
\text { Tüketimi }\end{array}$ & 0.646 & $\begin{array}{l}\mathrm{y}=183.100+0.633[\mathrm{AR}(1)]+0.291[\mathrm{AR}(2)]+1.002[\mathrm{AR}(3)]-0.893[\mathrm{AR}(4)]-0.315[\mathrm{AR}(5)]-0.754[\mathrm{AR}(6)] \\
+0.963[\mathrm{AR}(7)]+0.067[\mathrm{AR}(8)]+0.659[\mathrm{AR}(9)]-0.689[\mathrm{AR}(10)]-0.169[\mathrm{MA}(1)]-0.305[\mathrm{MA}(2)]- \\
1.190[\mathrm{MA}(3)]+0.633[\mathrm{MA}(4)]+0.466[\mathrm{MA}(5)]+0.875[\mathrm{MA}(6)]-0.831[\mathrm{MA}(7)]-0.237[\mathrm{MA}(8)]- \\
0.516[\mathrm{MA}(9)]+0.619[\mathrm{MA}(10)]\end{array}$ \\
\hline $\begin{array}{l}\text { Hidroelektrik } \\
\text { Güç Tüketimi }\end{array}$ & 0,851 & $\begin{array}{llllll}\mathrm{y}=233.410+1.878 & {[\mathrm{AR}} & (1)]-0.872[\mathrm{AR}(2)]-1.004[\mathrm{AR}(3)]+ & 0.866[\mathrm{AR}(4)]+1.009[\mathrm{AR}(5)] & - \\
1.868[\mathrm{AR}(6)]+ & 0.867[\mathrm{AR}(7)] & -1.024[\mathrm{MA}(1)] & -0.0508[\mathrm{MA}(2)]+ & 0.981[\mathrm{MA}(3)]+0.103[\mathrm{MA}(4)] & - \\
1.025[\mathrm{MA}(5)]+0.914[\mathrm{MA}(6)] & & & & \\
\end{array}$ \\
\hline $\begin{array}{c}\text { Sanayi Uretim } \\
\text { Endeksi }\end{array}$ & 0,913 & $y=-5 E-07 x 2+0,0454 x-841,98$ \\
\hline $\begin{array}{l}\text { Toplam Fosil } \\
\text { Yakit Tüketimi }\end{array}$ & 0.849 & $\begin{array}{l}\mathrm{y}=6.358+1.997[\mathrm{AR}(1)]-0.997[\mathrm{AR}(2)]-1.001[\mathrm{AR}(3)]+0.998[\mathrm{AR}(4)]+1.000[\mathrm{AR}(5)]-1.996[\mathrm{AR}(6)]+ \\
0.997[\mathrm{AR}(7)]-1.759[\mathrm{MA}(1)]+0.727[\mathrm{MA}(2)]+1.055[\mathrm{MA}(3)]-0.776[\mathrm{MA}(4)]-1.030[\mathrm{MA}(5)]+ \\
1.739[\mathrm{MA}(6)]-0.725[\mathrm{MA}(7)]\end{array}$ \\
\hline $\begin{array}{l}\text { Nükleer Enerji } \\
\text { Tüketimi }\end{array}$ & 0.905 & $\begin{array}{l}\mathrm{y}=0.593+0.850[\mathrm{AR}(1)]+0.308[\mathrm{AR}(2)]-0.736[\mathrm{AR}(3)]+0.004[\mathrm{AR}(4)]+1.155[\mathrm{AR}(5)]-0.584[\mathrm{AR}(6)] \\
-0.273[\mathrm{MA}(1)]-0.357[\mathrm{MA}(2)]+0.532[\mathrm{MA}(3)]+0.291[\mathrm{MA}(4)]-0.9291[\mathrm{MA}(5)]+0.104[\mathrm{MA}(6)]\end{array}$ \\
\hline $\begin{array}{l}\text { Toplam Enerji ile } \\
\text { ilișkili COO } \\
\text { Emisyonu }\end{array}$ & 0.804 & 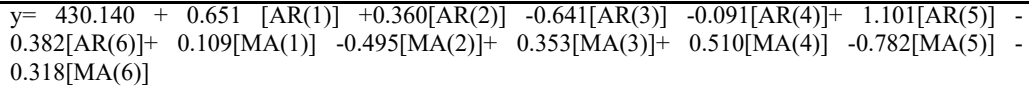 \\
\hline
\end{tabular}

Değişkenlere ait tanımlayıcı istatistiklere Tablo 2'de yer almaktadır.

\footnotetext{
${ }^{4}$ Değişkenlere ait trend ve ARMA denklemleri Excel ve Eviews 9 ekonometri programlarından elde edilmiştir.
} 
Tablo 2. ABD’nin Enerji Kaynaklarına Ait Tanımlayıcı İstatistikler

\begin{tabular}{l|l|l|l|l|l|l|l|l}
\hline $\begin{array}{l}\text { Tanım. } \\
\text { İstatistik }\end{array}$ & $\begin{array}{l}\text { Biyoyakıt } \\
\text { Tük. }\end{array}$ & $\begin{array}{l}\text { T.Biyokütle } \\
\text { Enerji Tük. }\end{array}$ & $\begin{array}{l}\text { Odun } \\
\text { Enerji } \\
\text { Tük. }\end{array}$ & $\begin{array}{l}\text { Hidroelektrik } \\
\text { Enerji Tük. }\end{array}$ & $\begin{array}{l}\text { Sanayi } \\
\text { Üretim } \\
\text { Endeksi }\end{array}$ & $\begin{array}{l}\text { T.Fosil } \\
\text { Yakıt } \\
\text { Tük. }\end{array}$ & $\begin{array}{l}\text { Nükleer } \\
\text { Elektrik } \\
\text { Güç Tük. }\end{array}$ & $\begin{array}{l}\text { Toplam } \\
\mathrm{CO}_{2} \\
\text { Emisyo }\end{array}$ \\
\hline Ortalama & 71,24 & 290,45 & 180,46 & 234,27 & 89,18 & 6,65 & 0,63 & 458,35 \\
\hline Ortanca & 32,47 & 267,03 & 174,71 & 230,56 & 93,9 & 6,63 & 0,64 & 458,32 \\
\hline $\begin{array}{l}\text { Standart } \\
\text { Sapma }\end{array}$ & 67,55 & 64,26 & 20,81 & 45,93 & 14,14 & 0,55 & 0,08 & 38,75 \\
\hline Min Değer & 7,25 & 178,54 & 128,7 & 145,71 & 62,42 & 5,51 & 0,35 & 383,66 \\
\hline Mak. Değer & 204,08 & 434,35 & 252,9 & 357,38 & 106,61 & 8,1 & 0,77 & 557,62 \\
\hline Gözlem Sayıs1 & 345 & 345 & 345 & 345 & 345 & 345 & 345 & 345 \\
\hline
\end{tabular}

\section{Analiz Yöntemi}

Hem finansal hem de ekonomik zaman serilerinde temel spektral ayrıştırma tekniklerinin başında Fourier ve dalgacık dönüşümleri gelmektedir. Spektral ayrıştırma tekniklerinden birisi olan Fourier dönüşümü, zaman alanındaki bir sinyalin içeriğinin analizine imkân veren bir dönüşüm tekniğidir. Fourier dönüşümünde, zaman alanındaki bir fonksiyon, frekans alanında bir fonksiyona dönüştürülür. Daha sonra fonksiyonun Fourier katsayıları her frekans için analiz edilir (Graps, 1995, s.52).

Dolayısıyla, Fourier dönüşümü frekans-frekans (frequency-by-frequency) temelinde bir ayrışma olarak görülebilmektedir (Gençay et al., 2002, s.2). Fourier dönüşümü, bir sinyalin içerdiği frekansları gösterirken, hangi zaman diliminde hangi frekansların mevcut olduğu hakkında bilgi vermemektedir. Yani, Fourier dönüşümü belirli noktadaki zamana ait bilgiyi değil, bütün zaman dilimine ait bilgiyi vermektedir. Dolayısıyla Fourier dönüşümü, frekansı zamana göre değişmeyen sinyallerin analizinde başarılı bir yaklaşımdır (Arı vd., 2008, s.1). Başka ifadeyle, Fourier temel fonksiyonu (sinüsler ve kosinüsler), sabit zaman serileri yani durağan zaman serileri ile çalışırken uygun bir yöntemdir (Bkz., Ek A). Ancak çoğu zaman, ekonomik/finansal zaman serileri; eğilimler, ani değişimler ve dalgalanmalar gibi nedenlerle zaman içinde oldukça karmaşık durumlar sergilediğinden dolayı analizleri, durağan zaman serileri ile sınırlamak doğru değildir. Ayrıca, serilerin durağan olmadığı durumlarda, seriler zaman içerisinde görülebilir, kaybolabilir ve sonra tekrar ortaya çıkabilirler. Fourier analizi gibi geleneksel sinyal analiz araçları, bu frekans değişimlerini kaçırabilmektedirler. Bu nedenle durağan olmayan zaman serilerinde, Fourier dönüşümü karmaşık olayları etkili bir şekilde tespit edememektedir (Gençay et al., 2002, s.2). Bahsedilen bu eksikliklerden dolayı çalışmada ölçek tabanlı analiz yöntemi olan "dalgacık analiz yöntemi” kullanılmıştır.

Dalgacık dönüşümü, Fourier dönüşümü ile karşılaştırıldığında daha yeni ve daha karmaşık bir yöntemdir. Bu dönüşüm, Fourier dönüşümü ile benzer matematiksel temele sahip olmasının yanı sıra ölçekleme adı verilen yeni bir özelliğe de sahiptir. Dalgacık dönüşümü hem frekans hem de zaman alanında eşzamanlı olarak zaman serilerini analiz eder. Durağan olmayan zaman serileri için en iyi tekniklerden birisi olan dalgacık dönüşümü, frekansın, farklı frekans bantlarına ayrılması, zaman diliminde bölümlere ayrılması ve böylece kendi frekans içeriklerinin analiz edilmesine imkan tanıyan bir yöntemdir (Zhao et al., 2004, s.1). Dalgacık fonksiyonu (veya anne dalgacık fonksiyonu), ölçeklendirme fonksiyonunun doğrusal bir kombinasyonu olarak da ifade edilebilmektedir. 
Bununla birlikte, $\omega \in \mathbb{R}$ and $m \in \mathbb{R}^{+}$, olmak şartıyla, her ölçeklenmiş ve dönüştürülmüş dalgacık fonksiyonu $\beta_{(m, \omega)}(t)$ anne dalgacığa göre aşağıdaki gibi yazılabilmektedir:

$\beta_{(\mathrm{m}, \omega)}(t)=\frac{1}{\sqrt{\mid \underline{|m|}}} \beta\left(\frac{t-\omega}{m}\right)$

Burada $1 / \sqrt{|m|}$ terimi dalgacığın birim varyansını belirleyen normalleşmeyi temsil eden faktördür. Anne dalgacığı temsil eden $\beta($.$) ise iki kontrol parametresi olan m (ölçek) ve \omega$ (konum)'yi de içermektedir. Parametre $\omega$, dönüşüm ya da konum parametresidir. Bu değişken, zaman alanında dalgacığın konumunu ve pozisyonunu kontrol etmektedir. Eşitlikteki m ise dalgacık genişliğini kontrol eden parametredir. Ayrıca dalgacığın pozisyonunu ve frekans alanındaki konumunu da gösterir. Frekans açısından değerlendirildiğinde, hızlı değişen detaylar daha düşük ölçeklerde, yani yüksek frekanslarda yakalanabilirken, daha yavaş değişen detaylar daha yüksek ölçeklerde, yani düşük frekansları yakalanabilmektedir. Bu durum frekans ve ölçek arasında negatif bir ilişki olduğunu göstermektedir. Sürekli dalgacık dönüşümü (SDD), dalgacık $\beta_{(m, \omega)}(t)$ ile ilgili olarak, $\ddot{x}(t) \in L^{2}(\mathbb{R})$ 'nin incelenen zaman serisine belirli bir dalgacık, $\beta($. ), olarak aşağıdaki gibi yazılabilir:

$W_{\ddot{\mathrm{x}}}(\mathrm{m}, \omega)=\int_{-\infty}^{\infty} ¥(t) \frac{1}{\sqrt{|m|}} \beta^{*}\left(\frac{t-\omega}{m}\right) d t$

Burada $W_{\ddot{x}}(m, \omega) \operatorname{SDD}^{51}$ yi temsil etmektedir. Denklemdeki * karmaşı eşlenmeyi (complex conjugation) göstermektedir.

Diğer taraftan, küçük bir dalga olarak tanımlanan dalgacıklar genellikle aynı özelliklere sahip değillerdir. Bu bağlamda, dalgacıklar kendi özelliklerine göre farklı gruplara ayrılırlar. Bu dalgacıkların; Haar, Daubechies, Symlets, Coiflets, Biorthogonal, Gauss, Meksika şapkası, Morlet, Meyer, Shannon gibi türleri vardır. Morlet dalgacık dönüşümü hem hayali hem de gerçek kısımlara sahiptir, böylelikle hem faz hem de genliği analiz etme imkani sağlar. Morlet dalgacık fonksiyonu şu şekilde yazılabilmektedir:

$\lambda_{\varphi}(t)=\pi^{-1 / 4}\left(\exp ^{i \varphi t}-\exp ^{-\varphi^{2} / 2}\right) \exp ^{-t^{2} / 2}$

Burada $\varphi$ parametresi, Morlet dalgacı̆̆ının $\lambda_{\varphi}(t)$ merkezi frekans parametresini göstermektedir. Ayrıca $\varphi$ Gauss zarfı içindeki salınımların sayısını kontrol etmektedir. $\mathrm{Bu}$ bağlamda $\varphi^{\prime}$ yı artırarak daha iyi frekans lokasyonu sağlamak mümkündür (Addison, 2002). Denklemdeki $\exp ^{-\varphi^{2} / 2}$ terimi karmaşık sinüs dalgasının sıfır olmayan ortalamasını düzelten,

\footnotetext{
5 Bir fonksiyonun SDD olarak kabul edilebilmesi için aşağıdaki şartları taşıması gerekmektedir (Conraria and Soares, 2013, s. 391);

- $\quad \beta(.)^{\prime}$ 'nın integrali sıfırdır.

$\int_{-\infty}^{\infty} \beta(t) d t=0$,

- $\quad \beta(.)^{\prime}$ nın karesinin integrali 1'e eşittir.,

$\int_{-\infty}^{\infty}|\beta(t)|^{2} d t=1$,

- $\quad$ Kabul edilebilirlik şartı$$
¥_{\partial}=\int_{0}^{\infty} \frac{|\theta(\mathcal{N})|^{2}}{\mathcal{N}} d \mathcal{N}<\infty,
$$ 
düzeltme parametresidir. Ancak $\varphi>5$ olduğu zaman bu durum ihmal edilebilmektedir. Morlet dalgacık fonksiyonunun basitleştirilmiş versiyonu ise:

$\lambda_{\varphi}(t)=\pi^{-1 / 4} \exp ^{\mathrm{i} \varphi \mathrm{t}} \exp ^{-\mathrm{t} / 2}$

Burada $\varphi$ için 6 değeri kabul edilebilirlik koşulunu sağlarken, $\lambda$ ise eşitliğin Fourier peryodunu temsil etmektedir (Farge, 1992). SDD'ne ek olarak, incelenen zaman serilerinin enerjisi veya varyansı korunmaktadır. Bu durumu aşağıdaki denklemle gösterilebilmektedir.

$\|\ddot{\mathrm{x}}\|^{2}=(¥ \emptyset)^{-1} \int_{0}^{\infty}\left[\int_{-\infty}^{\infty}\left|W_{\ddot{\mathrm{x}}}(m, \omega)\right|^{2} d \omega\right] \frac{d \underline{m}}{m^{2}}$

Burada, dalgacık güç spektrumu olan $\left|W_{\ddot{x}}(m, \omega)\right|^{2}$, $\ddot{x}(t)$ 'nin hem frekans hem de zaman alanında enerji dağılımını göstermektedir. Ayrıca, bu özellik dalgacık korelasyonunu, dalgacık varyansı ve dalgacık kovaryansını tanımlamak için kullanılmaktadır. İki zaman serisinin çapraz dalgacık gücü ${ }^{6}$ (cross-wavelet power), $W_{x y}(m, \omega)$ zaman serileri arasında her ölçekte (frekans band1) ve her zamanda yerel kovaryans olarak tanımlanabilmektedir. İki zaman serisinin $x(t)$ ve $y(t)$ çapraz dalgacık gücü ilk olarak Hudgins vd. (1993) tarafından aşağıdaki gibi tanımlanmıştır:

$W_{x y}(m, \omega)=W_{x}(m, \omega) \overline{W_{y}(m, \omega)}$

Burada, $W_{x}(m, \omega)$ ve $W_{y}(m, \omega), W_{x y}(m, \omega)$ olarak $x(t)$ ve $y(t)$ 'nin zaman serilerinin SDD 'dir. Yani çapraz dalgacık gücüdür. Ayrıca denklemde ṃ ölçeği temsil ederken, $\omega$ konum parametresidir. Çapraz dalgacık dönüşümleri, her iki zaman serisinde ve her bir ölçekte zaman serileri arasındaki yerel kovaryansı temsil eden yüksek ortak güce sahip alanları göstermektedir (Vacha and Barunik, 2012, s.243).

Aguiar-Conraria et al. (2013), göre $W_{x}(m, \omega)$ ve $W_{y}(m, \omega)$ iki zaman serisinin dalgacık uyumunu (wavelet coherency) aşağıdaki gibi tanımlamaktadır:

$R_{x y}(m, \omega)=\frac{\left|\mathcal{S}\left(W_{x y}(m, \omega)\right)\right|}{\left|\mathcal{S}\left(\left|W_{x x}(m, \omega)\right|\right)\right|^{1 / 2}\left|\delta\left(\left|W_{y y}(m, \omega)\right|\right)\right|^{1 / 2}}$

Denklem 7'de $R_{x y}$ korelasyonu temsil etmektedir. Bu değer 0-1 arasında değișen bir parametredir. Eğer hem zaman hem de frekans alanında güçlü tutarlılık varsa korelasyon "1" e, eğer tutarlılık yok ise korelasyon " 0 " a eşit olacaktır. Ek olarak, $\mathcal{S}$ gerekli olan düzeltme (smoothing) parametresini ifade etmektedir. Bu düzeltme olmaz ise, tutarlılık her zaman güçlü yani “1” olacaktır. Faz farkı analizi, örneğin korelasyon yönü (pozitif ve negatif korelasyon) ve öncül ve geride (lead or lag) kalan ilişkisi gibi bileşenler arasındaki faz ilişkilerini tespit etmeye de imkân tanımaktadır. $x(t)$ ve $y(t)$ zaman serileri arasındaki faz farkı $\left(\xi_{x, y} \in[-\pi, \pi]\right.$ ile $)$ ilişkisi şu şekilde tanımlanabilmektedir:

$\xi_{x, y}(m, \omega)=\frac{1}{\tan }\left(\frac{\jmath\left(W_{x y}(m, \omega)\right)}{\mathfrak{N}\left(W_{x y}(m, \omega)\right)}\right)$

\footnotetext{
${ }^{6} x=y$ olduğunda çapraz dalgacık gücü (cross-wavelet power) elde edilir.
} 
Yukarıdaki denklemde, $\mathcal{J}\left(W_{x y}\right)$ ve $\mathfrak{N}\left(W_{x y}\right)$ sırasıyla hayali ve gerçek bölümleri temsil etmektedirler. Eğer, $\xi_{x y} \in\left(0, \frac{\pi}{2}\right)$ ise, seri fazda hareket edecek ve $x(t) \rightarrow y(t)$ 'ye öncülük edecektir. Eğer $\xi_{x y} \in\left(0,-\frac{\pi}{2}\right)$ ise, seri tekrar fazda hareket edecek ve bu durumda $y(t)$ öncü durumdadır. Eğer $\xi_{x, y} \in\left(\frac{\pi}{2}, \pi\right)$ ise, değişkenler arasında anti-faz ilişkisi vardır, bu durumda seri fazın dışına hareket edecektir ve $y(t)$ öncü durumdadır. Faz farkı $\pi$ veya $-\pi$ olduğunda bu durum anti-faz ilişkisi olduğunu göstermektedir. Eğer $\xi_{x, y} \in\left(-\pi,-\frac{\pi}{2}\right)$ ise anti-faz ilişkisi vardır ve $x(t)$ öncü konumdadır. Son olarak, faz farkı sıfırda ise bu durumda, $y(t)$ ve $x(t)$ birlikte hareket edeceklerdir.

\section{Analiz Bulguları}

ABD ekonomisi, 1989:1-2017:8 dönemine ait enerji tüketim (biyoyakıt tüketimi ve biyokütle enerjisi tüketimi) oranları ile $\mathrm{CO}_{2}$ emisyonu arasındaki ilişkiyi araştırmak için dalgacık ve dalgacık uyumu yöntemlerinden birisi olan Morlet Dalgacık Uyumu Modeli tercih edilmiştir. Analiz sonuçlarına sırasıyla aşağıda yer verilmiştir. Öncelikle enerji tüketim verileri ile $\mathrm{CO}_{2}$ emisyonu arasındaki dalgacık uyumu dikkate alınmış, ardından analizin güvenilirliği için kontrol değişkenlerin dahil edildiği dalgacık uyumu incelenmiştir. Dalgacık uyumu sonuçlarının tamamı sırasıyla, 1 3 frekans bandı ve 3 8 frekans bandında yorumlanmıştır.
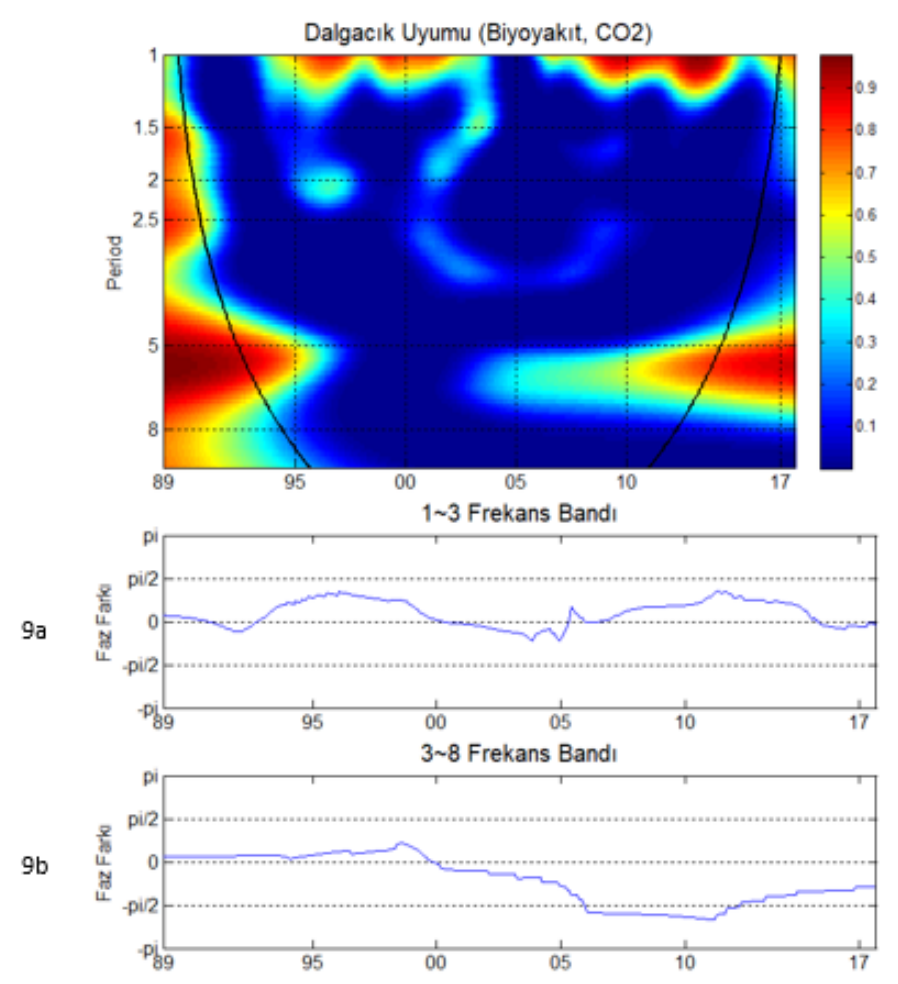

Şekil 9. Kısmi dalgacık uyumu (Biyoyakıt, $\mathrm{CO}_{2}$ ) 
i. Şekil 9'da siyah eğri (kontur), ARMA $(1,1)$ gösterimi vasitasıyla tahminin \%5'lik anlam düzeyini belirtmektedir.

ii. ARMA modeli bakımından AR (1) ve MA (1) terimleri, sırasıly bir gecikmeli otoregresif modeli ve bir gecikmeli hareketli ortalamayı temsil etmektedir.

iii. Şekil 9'un yanında ki renk kod çubuğu, değişkenler arasındaki zayıf tutarlılıktan (mavi), güçlü tutarlılığa (kırmızıya) kadar olan aralığı göstermektedir.

Şekil 9a'da 1989:1'den, 2017:8'e kadar 1 3 frekans bandında ABD’nin biyoyakıt kullanımı ve toplam enerji ile ilişkili $\mathrm{CO}_{2}$ emisyonu arasındaki faz farkı yer almaktadır. Şekil 9b'de 1989:1'den, 2017:8'e kadar 3 8 frekans bandında ABD'nin biyoyakıt kullanımı ve toplam enerji ile ilişkili $\mathrm{CO}_{2}$ emisyonu arasındaki faz farkı yer almaktadır. Şekil 9 dikkate alındığında, iki değişken arasındaki ilişkinin net olmadığı veya zayıf izlenebildiği görülmektedir. Bu nedenle kontrol değişkenlerin modele dahil edildiği kısmi dalgacık analizleri takip edilecektir.

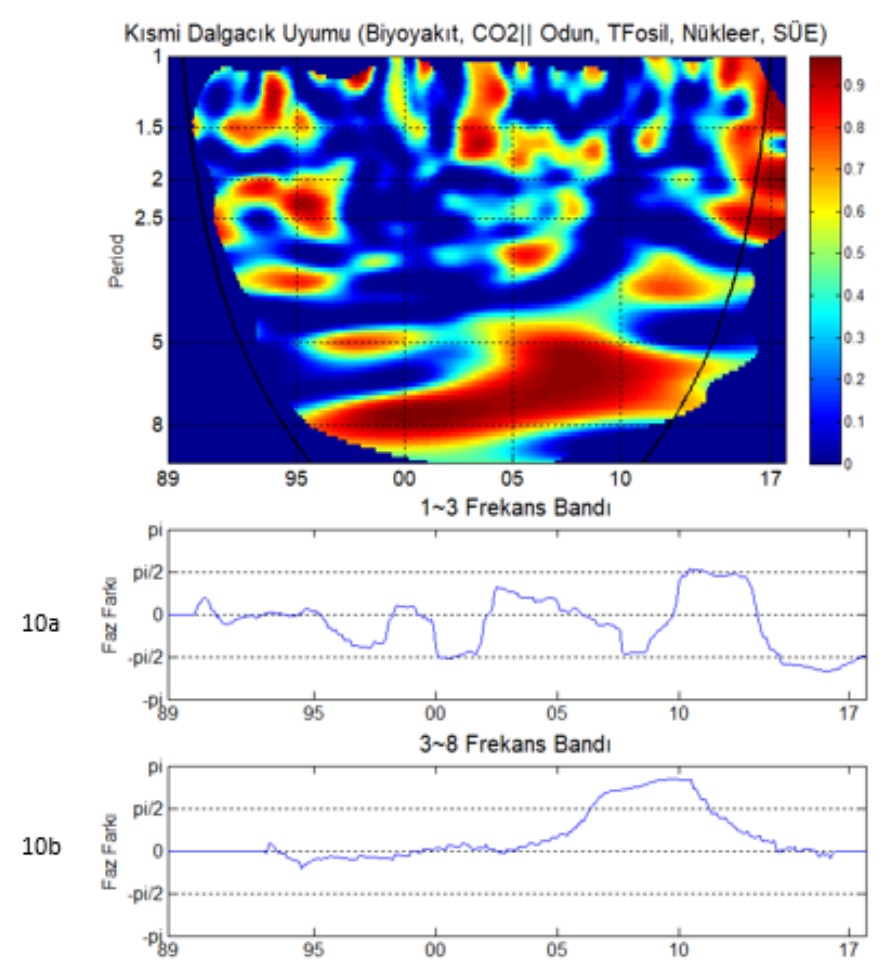

Şekil 10. Kısmi dalgacık uyumu (Biyoyakıt, $\mathrm{CO}_{2}$, Odun, TFosil, Nükleer, SÜE)

i. Şekil 10'da siyah eğri (kontur), ARMA $(1,1)$ gösterimi vasitasıyla tahminin \%5'lik anlam düzeyini belirtmektedir.

ii. ARMA modeli bakımından AR (1) ve MA (1) terimleri, sirasiyla bir gecikmeli otoregresif modeli ve bir gecikmeli hareketli ortalamayı temsil etmektedir.

iii. Şekil 10'un yanında ki renk kod çubuğu, değişkenler arasındaki zayıf tutarlılıktan (mavi), güçlü tutarlılığa (kırmızıya) kadar olan aralığı göstermektedir. 
Şekil 10, Şekil 9'daki modele bazı kontrol değişkenlerin eklenmesi ile elde edilmiştir. Böylece modele yeni kontrol değişkenler dâhil ederek biyoyakıt tüketimi ve toplam enerji ile ilişkili $\mathrm{CO}_{2}$ emisyonu arasındaki ilişkiyi gösteren dalgacık uyumu yeniden incelenmiştir. Söz konusu kontrol değişkenler sırasıyla; odun enerji tüketimi (Odun), toplam fosil yakıt tüketimi (TFosil), nükleer enerji tüketimi (Nükleer) ve sanayi üretim endeksi (SÜE)'dir. Bu iki değişken arasındaki korelasyonunun yönünü anlamak için (hangi değişkenin diğerine öncül olduğunu anlayabilmek için) aşağıdaki faz farkı analizlerinin takip edilmesi gerekmektedir.

Şekil 10a' da 1989:1'den, 2017:8'e kadar (Odun, TFosil, Nükleer, SÜE kontrol değişkenleri dalgacık modeline dâhil edildikten sonra) 1 3 frekans bandında ABD’nin biyoyakıt kullanımı ve toplam enerji ile ilişkili $\mathrm{CO}_{2}$ emisyonu arasındaki faz farkı yer almaktadır. Değişkenlerin pozitif korelasyona sahip olduğu faz aralığı dikkate alındığında; biyoyakıt kullanımının, 19901991:6, 1999:1-1999:12, 2002:9-2006:7 ve 2011-2013:7 dönemlerinde $\mathrm{CO}_{2}$ emisyonunu artırdı̆̆ gözlemlenmektedir. Benzer şekilde $\mathrm{CO}_{2}$ emisyonu; 1991:7-1992, 1995-1998, 2000:1-2000:12, 2006:8-2009 ve 2014:1-2014:7 dönemlerinde biyoyakıt kullanımını artırmaktadır. Değişkenlerin negatif korelasyona sahip olduğu faz aralığı dikkate alındığında; biyoyakıt kullanımının 2014:8-2016 döneminde $\mathrm{CO}_{2}$ emisyonunu azalttığı belirlenmiştir.

Şekil 10b' de 1989:1'den, 2017:8'e kadar (Odun, TFosil, Nükleer, SÜE kontrol değişkenleri dalgacık modeline dahil edildikten sonra) 3 8 frekans bandında ABD’nin biyoyakıt kullanımı ve toplam enerji ile ilişkili $\mathrm{CO}_{2}$ emisyonu arasındaki faz farkı yer almaktadır. Değişkenlerin pozitif korelasyona sahip olduğu faz aralığı dikkate alındığında; biyoyakıt kullanımı, 20002006:9 ve 2011:10-2015 dönemlerinde $\mathrm{CO}_{2}$ emisyonunu artırdığ gözlemlenmektedir. Benzer şekilde, $\mathrm{CO}_{2}$ emisyonu; 1994-1999 döneminde biyoyakıt kullanımını artırmaktadır. Değişkenlerin negatif korelasyona sahip olduğu faz aralığı dikkate alındığında $\mathrm{CO}_{2}$ emisyonu; 2006:10-2011:9 döneminde biyoyakıt kullanımını azaltmaktadır.
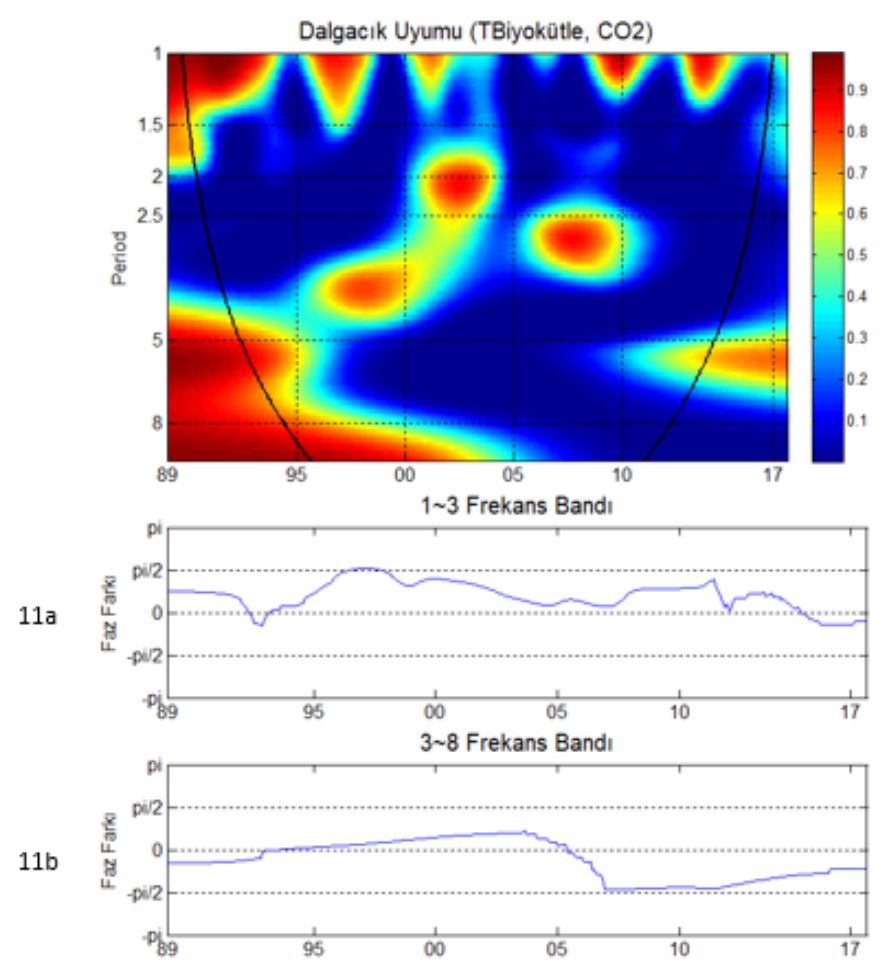

Şekil 11. Kısmi dalgacık uyumu (TBiyokütle, $\mathrm{CO}_{2}$ ) 
i. Şekil 11'de siyah eğri (kontur), ARMA $(1,1)$ gösterimi vasitasıyla tahminin \%5'lik anlam düzeyini belirtmektedir.

ii. ARMA modeli bakımından AR (1) ve MA (1) terimleri, sirasiyla bir gecikmeli otoregresif modeli ve bir gecikmeli hareketli ortalamayı temsil etmektedir.

iii. Şekil 11'in yanında ki renk kod çubuğu, değişkenler arasındaki zayıf tutarlılıktan (mavi), güçlü tutarlılığa (kırmızıya) kadar olan aralığı göstermektedir.

Şekil 11a' da 1989:1'den, 2017:8'e kadar 1 3 frekans bandında ABD’nin toplam biyokütle enerji kullanımı ve toplam enerji ile ilişkili $\mathrm{CO}_{2}$ emisyonu arasındaki faz farkı yer almaktadır. Şekil 3b' de 1989:1'den, 2017:8'e kadar 3 8 frekans bandında ABD'nin toplam biyokütle enerji kullanımı ve toplam enerji ile ilişkili $\mathrm{CO}_{2}$ emisyonu arasındaki faz farkı yer almaktadır. Şekil 11 dikkate alındığında, iki değişken arasındaki ilişkinin net olmadığı veya zayıf izlenebildiği görülmektedir. Bu nedenle kontrol değişkenlerin modele dahil edildiği kısmi dalgacık analizleri takip edilecektir.

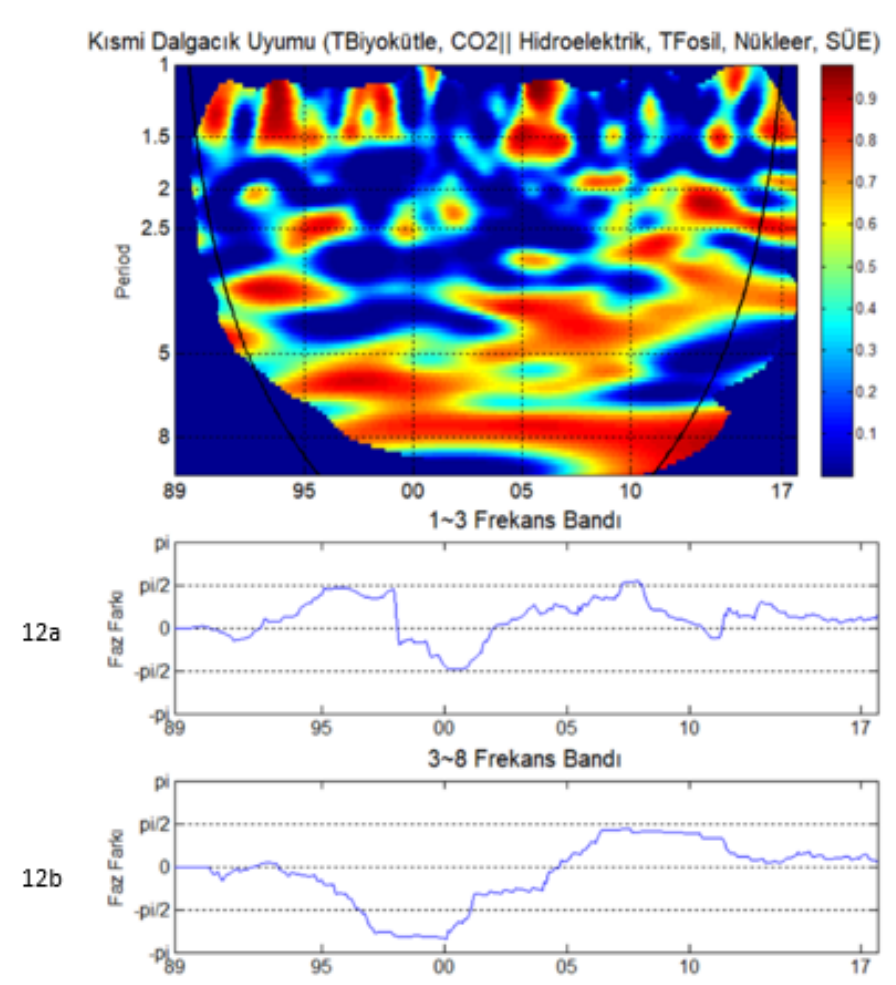

Şekil 12. Kısmi dalgacık uyumu (TBiyokütle, $\mathrm{CO}_{2}$, Hidroelektrik, TFosil, Nükleer, SÜE)

i. Şekil 12'de siyah eğri (kontur), ARMA $(1,1)$ gösterimi vasıtasıly tahminin \%5'lik anlam düzeyini belirtmektedir.

ii. ARMA modeli bakımından AR (1) ve MA (1) terimleri, sırasıyla bir gecikmeli otoregresif modeli ve bir gecikmeli hareketli ortalamayı temsil etmektedir.

iii. Şekil 12'nin yanında ki renk kod çubuğu, değişkenler arasındaki zayıf tutarlılıktan (mavi), güçlü tutarlılığa (kırmızıya) kadar olan aralığı göstermektedir. 
Şekil 12, Şekil 11'deki modele bazı kontrol değişkenlerin eklenmesi ile elde edilmiştir. Böylece modele yeni kontrol değişkenler dâhil ederek toplam biyokütle enerji tüketimi ve toplam enerji ile ilişkili $\mathrm{CO}_{2}$ emisyonu arasındaki ilişkiyi gösteren dalgacık uyumu yeniden incelenmiştir. Söz konusu kontrol değişkenler sırasıyla; hidroelektrik tüketimi (Hidroelektrik), toplam fosil yakıt tüketimi (TFosil), nükleer enerji tüketimi (Nükleer) ve sanayi üretim endeksi (SÜE)'dir. Bu iki değişken arasındaki korelasyonunun yönünü anlamak için (hangi değişkenin diğerine öncül olduğunu anlayabilmek için) aşağıdaki faz farkı analizlerinin takip edilmesi gerekmektedir.

Şekil 12a'da 1989:1'den, 2017:8'e kadar (Hidroelektrik, TFosil, Nükleer, SÜE kontrol değişkenleri dalgacık modeline dâhil edildikten sonra) 1 3 frekans bandında ABD’nin toplam biyokütle enerji kullanımı ve toplam enerji ile ilişkili $\mathrm{CO}_{2}$ emisyonu arasındaki faz farkı yer almaktadır. Değişkenlerin pozitif korelasyona sahip olduğu faz aralığı dikkate alındığında; toplam biyokütle enerji kullanımının, 1993-1998:9, 2005-2010 ve 2011:10-2016 dönemlerinde $\mathrm{CO}_{2}$ emisyonunu artırdığı gözlemlenmektedir. Benzer şekilde $\mathrm{CO}_{2}$ emisyonu; 1991:8-1992, 1998:9-1999, 2001:1-2001:12 ve 2011:1-2011:9 dönemlerinde toplam biyokütle enerji kullanımını artırmaktadır. Son olarak 1990-1991:7 döneminde toplam biyokütle enerji ve $\mathrm{CO}_{2}$ emisyonu birlikte artmaktadır.

Şekil 12b'de 1989:1'den, 2017:8'e kadar (Hidroelektrik, TFosil, Nükleer, SÜE kontrol değişkenleri dalgacık modeline dahil edildikten sonra) 3 8 frekans bandında ABD'nin toplam biyokütle enerji kullanımı ve toplam enerji ile ilişkili $\mathrm{CO}_{2}$ emisyonu arasındaki faz farkı yer almaktadır. Değişkenlerin pozitif korelasyona sahip olduğu faz aralığı dikkate alındığında toplam biyokütle enerji; 1992-1993 ve 2005-2015 döneminde $\mathrm{CO}_{2}$ emisyonunu artırdı̆̆ gözlemlenmektedir. Benzer şekilde, $\mathrm{CO}_{2}$ emisyonu; 1994-1996 ve 2001:6-2004 dönemlerinde toplam biyokütle enerji kullanımını artırmaktadır. Değişkenlerin negatif korelasyona sahip olduğu faz aralığı dikkate alındığında; toplam biyokütle enerji kullanımı, 1997-2001:5 döneminde $\mathrm{CO}_{2}$ emisyonu azaltmaktadır.

\section{Sonuç}

Dünya yüzeyinde uzun dalga boylarına sahip radyasyonu tutan belirli gazlar bulunmaktadır (Mitchell, 1989). Sera gazları olarak adlandırılan bu gazlar, yeryüzü sıcaklığını artırarak doğal sera etkisine neden olmaktadır (Mitchell, 1989, s.115). Bu etki, atmosferdeki sera gazlarının sıcaklığı tutmaları neticesinde ortaya çıkmakta ve yeryüzünü, canlıların yaşayabileceği ortam sıcaklığına getirmektedir. Bu nedenle, doğal sera gazları ve sera etkisi yeryüzü için önemli ve gereklidir.

Genel olarak; atmosferdeki gazlar dikkate alındığında sera etkisinin temel belirleyicileri, $\mathrm{CO}_{2}$ ve $\mathrm{H}_{2} \mathrm{O}$ gazlarıdır. Doğal olarak atmosferde bulunan sera gazlarının seviyesi ve yoğunlukları zamanla değişebilmektedir. Bu değişimin en önemli kaynaklarından birisi, insan aktiviteleridir. Temel iki sera gazı açısından bakıldığında ise, insan faaliyetlerinin $\mathrm{CO}_{2}$ üzerinde doğrudan etkisi görülürken, su buharı üzerinde doğrudan etkisinin olmadığı görülmektedir (Wallington et al., 2009, s.7).

Canlı yaşamı için vazgeçilmez olan sera gazlarının emisyon yoğunluğunun aşırı artması ise beraberinde küresel ısınma sorununu getirmektedir. Günümüzde küresel ısınma kaynaklı 
tehdit, sanayileşme düzeylerine paralel olarak yüksek sera gazı salınımına sahip gelişmiş ülkeler başta olmak üzere tüm ülkelerin ortak sorunu haline gelmiştir. Bu nedenle de son yıllarda küresel ısınmayla mücadele konusu önemli araştırma konuları arasında yer almaya başlamıştır.

Çalışmada öncelikle enerji ve enerji kaynakları, sera etkisi, küresel ısınma ve ABD’nin enerji yapısı ele alınmıştır. Araştırmada, "dalgacık uyumu (wavelet coherence)" yöntemlerinden birisi olan Morlet Dalgacık Uyumu Modeli ile yenilenebilir enerji kullanımı ve $\mathrm{CO}_{2}$ emisyonu arasındaki mevcut olası tüm 'aynı yönde' ve 'tezat yönde' hareketlerin gözlemlenebilmesi amaçlanmıştır.

Dalgacık uyumu yöntemi, diğer zaman serisi analizlerden farklı olarak, değişkenlerin hem zaman hem de frekans boyutunda analiz edilmesine olanak sağlamaktadır. Dalgacık analizi ile, ilgili tüm zaman dönemi içerisinde ve alt dönemler içerisinde, iki değişken arasındaki, 'sürekli' ya da ‘süreksiz’ olabilecek nedenselliğin var olup olmadı̆̆ı araştırılmaktadır.

Makalede, 'takip eden' ve 'takip edilen, öncül' değişkenler arasındaki eş-anlı hareketler gözlemlenirken, diğer ilgili kontrol değişkenleri de ilgili modellerde istihdam edilmektedir. Böylece dalgacık ve kısmi dalgacık uyumu analizleri ile bu çalışma, değişkenler arasındaki nedenselliğin hangi dalga boyutunda mevcut olduğunu ve bu nedensellikte hangi değişkenin öncül ve hangi değişkenin takip eden değişken olduğu hakkında detaylı bilgi vermektedir.

Araştırmada dalgacık analiziyle, 1989:1-2017:8 dönemi ABD'nin yenilenebilir enerji (biyoyakıt enerji, toplam biyokütle enerji) kullanımı ve $\mathrm{CO}_{2}$ emisyonu arasındaki ilişki incelenmiştir. Morlet Dalgacık Uyumu Modeli sonuçlarına göre;

i. Biyoyakıt enerjisi kullanımı (Odun, TFosil, Nükleer ve SÜE kontrol değişken iken) 1 3 frekans bandında, 2014:8-2016 döneminde, $\mathrm{CO}_{2}$ emisyonunu azaltmaktadır.

ii. TBiyokütle enerjisi kullanımı (Hidroelektrik, TFosil, Nükleer ve SÜE kontrol değişken iken) 3 8 frekans bandında, 1997-2001:5 döneminde, $\mathrm{CO}_{2}$ emisyonunu azaltmaktadır.

Analiz bulguları, biyoyakıt ve toplam biyokütle enerji kullanımının $\mathrm{CO}_{2}$ emisyonunu azalttığı sonucuna ulaşmaktadır. Gelecekteki yapılacak araştırmalar ile olası sürekli dalgacık uyumu ve/veya kısmi sürekli dalgacık uyumu çalışmalarının takip edebileceği farklı ülke ve bölge analizleri önemli katkı(lar) sağlayabileceği öngörülmektedir. Bu durumda, ülkelerin enerji portföylerini oluştururken, enerji kullanımının çevreye boyutunu da göz önüne alarak, daha etkin enerji kullanımını sağlamaları gerekmektedir. Aynı zamanda, ülkeler sürdürülebilir kalkınma kapsamında bugünkü ve gelecekteki nesillerin doğal kaynaklara olan ihtiyaçlarını güvence altına almak istiyorlar ise yenilenebilir enerji kaynağı kullanımı ile ilgili politikaları ele almaları önemle üzerinde durulması gereken bir husustur. 


\section{Kaynakça}

Acaroğlu, M. (2001). Alternatif Enerji Kaynakları. Ankara: Nobel.

Addison, P. S. (2002). The Illustrated Wavelet Transform Handbook Introductory Theory and Application in Science. Engineering, Medicine and Finance, (1st Edition). Taylor\&Francis Group, CRS Press.

Aguiar-Conraria, L., Magalhães P.C., Soares, M.J. (2013). The Nationalization of Electoral Cycles in The United States: A Wavelet Analysis. Public Choice, 156(3-4), 387-408. doi:10.1007/s11127-012-0052-8.

Arı, N., Özen, Ş., Özen, Ö.H. (2008). Dalgacık Teorisi (Wavelet). Ankara: Palme.

Baek, J. (2015). Panel Cointegration Analysis of CO2 Emissions, Nuclear Energy and Income in Major Nuclear Generating Countries. Applied Energy, 145, 133-138. doi: https://doi.org/10.1016/j.a penergy.2015.01.074.

Bayraç, H. N. (2011). Enerji Kullanımının Küresel Isınmaya Etkisi ve Önleyici Politikalar. Eskişehir Osmangazi Üniversitesi Sosyal Bilimler Dergisi, 2(11), 229-260. http://dergipark.gov.tr/download/article-file/113309.

Bhattacharjee, A. (2012). Everything You Need to Know About the Types of Renewable Energy. Brainmass Inc.

Bilgili, F. (2012). The Impact of Biomass Consumption on CO2 Emissions: Cointegration Analyses with Regime Shifts. Renewable and Sustainable Energy Reviews, 16, 5349-5354. https://doi.org/10.1016/j.rser.2012.04.021.

Bilgili, F., Öztürk, İ., Koçak, E., Bulut, Ü., Pamuk, Y., Muğaloğlu, E., Bağlitaş, H.H. (2016). The Influence of Biomass Energy Consumption on CO2 Emissions: A Wavelet Coherence Approach. Environmental Science and Pollution Research, 23, 19043-19061. doi: 10.1007/s11356-016-7094-2.

Burrus, C.S., Gopinath, R.A., Guo, H. (1998). Introduction to Wavelets and Wavelet Transforms A Primer. New Jersey: Prentice Hall.

EIA (2017). U.S. Energy Information Administration, Independent Statistics and Analysis, International. erişim https://www.eia.gov/totalenergy/data/monthly/index.php.

EPA, U.S. Environmental Protection Agency (2015). Inventory of US. Greenhouse Gas Emissions and Sinks:1990-2013, USA.

Europa (2018). Fossil CO2 \& GHG emissions of all world countries, 2017. http ://edgar.jrc.ec.europa.eu/overview. php?v=CO2andGHG1970-2016\&sort=des9. 
Farge, M. (1992). Wavelet Transforms and Their Applications to Turbulence. Annual Reviews, 24, 395-457. doi:10.1146/annurev.fl.24.010192.002143.

Gençay R., Selçuk, F., Whitcher, B. (2002). An Introduction to Wavelets and Other Filtering Methods in Finance and Economics, San Diego: Academic.

Graps, A. (1995). An Introduction to Wavelets. IEEE Computational Science and Engineering, 2, 50-51. doi:10.1109/99.388960.

Hudgins L., Friehe CA., Mayer ME. (1993). Wavelet Transform and Atmospheric Turbulence. Physical Review Letters, 71(20), 3279-3282. doi:10.1103/PhysRevLett.71.3279.

Illing, L. (2008). Fourier analysis, http://www.reed.edu/physics/courses/Physics33 1.f08/pdf/Fourier.pdf.

IPCC. (2013). Climate Change 2013: The Physical Science Basis, Contribution of Working Group I to the Fifth Assessment Report of the Intergovernmental Panel On Climate Change [Stocker, T.F., D. Qin, G.-K. Plattner, M. Tignor, S.K. Allen, J. Boschung, A. Nauels, Y. Xia, V. Bex and P.M. Midgley (eds.)], Cambridge University Press, Camridge, United Kingdom and New York, NY, USA, 2013.

Irps, H. (2009). Energy Sources: Non Renewable and Renewable. Agriculturel Mechanization and Automation, 200-231. https://pdfs.semanticscholar.org/ae48/405362100745eb84792da0efb5de06b68c8b.pdf.

Iwata, H., Okada, K., Samreth, S. (2012). Empirical Study on the Determinants of CO2 Emissions: Evidence from OECD Countries. Applied Economics, 44, 3513-3519. doi: https://doi.org/10.1080/00036846.2011.577023.

Jalil, A., Mahmud, S. F. (2009). Environment Kuznets Curve for CO2 Emissions: A Cointegration Analysis for China. Energy Policy, 37, 5167-5172. doi: https://doi.org/10.1016/j.enpol.2009.07.044.

Kayfeci, M. (2011). Alternatif Enerji Kaynakları. https://staff.emu.edu.tr/mustafailkan /tr/documents/elet319/.../materyal5.pdf.

Aguiar-Conraria, L., Soares, M.J. (2014). The Continuous Wavelet Transform: Moving Beyond Uni-And Bivariate Analysis. Journal of Economics Survey, 28(2), 344-375. doi: http://dx.doi.org/10.1111/joes.12012.

Menyah, K., Wolde- Rufael Y. (2010). CO2 Emissions, Nuclear Energy, Renewable Energy and Economic Growth in the US. Energy Policy, 38, 2010, 2911-2915. doi: https://doi.org/10.1016/j.enpol.2010.01.024.

Mitchell, J. F.B. (1989). The Greenhouse Effect and Climate Change. Reviews of Geophysics, 27 (1), 115-139. doi: https://doi.org/10.1029/RG027i001p00115. 
Morlet, J., Grossmann, A. (1984), Decomposition of Hardy Functions Into Square Integrable Wavelets of Constant Shape. SIAM Journal on Mathematical Analysis, 15(4), 723-736. doi: https://doi.org/10.1137/0515056.

Saboori, B., Subiman, J. (2013). CO2 Emission Energy Consumption and Economic Growth in Association of Southwest Asian Nations (ASEAN) Countries: A Cointegration Approach. Energy, 55, 813-822. doi: https://doi.org /10.1016/j.energy.2013.04.038.

Say, N.P., Yücel, M. (2016). Energy Consumption and CO2 Emissions in Turkey: Empirical Analysis and Future Projection Based on Economic Growth, Energy Policy, 34(18), 38703876. doi: https://doi.org/10.10 16/j.enpol.2005.08.024.

Sorensen, T.C. (2016). Global Warming and Impacts on Climate of India, https://www.researchgate.net/profile/S_Sarvade/post/What_is_the_impact_of_global_w arming_on_the_environment/attachment/59d64bf079197b80779a5db0/AS\%3A4823663 22941955\%401492016501665/download/3113.pdf.pdf .

Soytas, U., Sarı, R. (2009). Energy Consumption, economic growth and Carbon Emissions: Challenges Faced by an EU Candidate Member. Ecological Economics, 68(6), 1667-1675. doi: https://doi.org/10.1016/j. ecolecon.2007.06.014.

Soytaş, U., Sarı,R., Ewing, B.T. (2007).Energy Consumption, Income and Carbon Emissions in the United States. Ecological Economics, 62(3-4), 482-489. doi: https://doi.org/10.1016/j.ecolecon.2006.07.009.

Tuna, M. (2000). Çevresel Sorunların Küreselleşmesi. Muğla Üniversitesi SBE Dergisi, 1(2), 1 16. http://dergipark.gov.tr/download/article-file/217462.

Vacha, L., Barunik, J. (2012). Co-Movement of Energy Commodities Revisited: Evidence from Wavelet Coherence Analysis. Energy Economics, 34(1), 241-247.doi: https://doi.org/10.1016/j.eneco.2011.10.007

Wallington, T.J., Srinivasan, J., Nielsen, O.J., Highwood, E.J. (2016). Greenhouse Gases and Global Warming, Encyclopedia of Life Support Systems (EOLSS). https://www.eolss.net/sample-chapters/C06/E6-13-01-01.pdf.

WES, (2015). World Energy Scenario Energy. [R]evolution A Sustainable World Outlook 2015, Greenpeace.

Worldenergy, Energy Resources: Biomass, 2018. erişim https://www.worldenergy.org/data /resources/resource/biomass/

Yousefi, M., Khoramivafo, M., Mondani, F. (2014). Integrated Evaluation of Energy Use, Greenhouse Gas Emissions and Global Warming Potential for Sugar Beet (Beta Vulgaris) Agroecosystems in Iran. Atmospheric Environmental, 92, 501-505. Doi: https://doi.org/10.1016/j.atmosenv.2014.04.050. 
Zhang, X.P., Mei, X. (2009). Energy Consumption, Carbon Emissions and Economic Growth in China. Ecological Economics, 68(10), 2706-2712.doi: https://doi.org/10.1016/j.ecolecon.2009.05.011.

Zhao, G., Jiang, D., Diao, J., Qian, L. (2004). Application of Wavelet Time-Frequency Analysis on Fault Diagnosis for Steam Turbine, In:5th International Conference of Acoustical and Vibratory Surveillance Methods and Diagnostic Techniques, France, CETIM.

EK - A

Fourier Dönüşümü 
Fourier serileri için sinüs dalgaları ana fonksiyon olarak seçilir. Ardından ortaya çıkan genleşmenin özellikleri incelenir (Burrus et al., 1998, s.xi). Fourier dönüşümünün matematiksel ifadesi, aşağıdaki denklemlerle açıklanmıştır:

$f(£+T)=f(£)$

Denklem 1'deki fonksiyonu $2 \pi$ periyotlu yapmak için, $\tau$ değeri yeni bir bağımsız değişken olarak, $t=\frac{2 \pi}{T} \tau$, tanımlanır. Sonuç olarak:

$f(t+2 \pi)=f(t)$

olur. Fonksiyon periyodik olduğu için sadece $2 \pi$ uzunluğunda bir aralıkta davranışını dikkate almamız gerekir. Joseph Fourier (1768-1830)'dan sonra sinüs ve kosinüs fonksiyonlarının sonsuz toplamı göz önünde bulundurularak Fourier serisi denklem 3'teki forma dönüşmüştür.

$f(x)=\frac{a_{0}}{2}+\sum_{m=1}^{\infty}\left[a_{m} \cos (m t)+b_{m} \sin (m t)\right]$

Denklem 3'teki $a_{n}$ ve $b_{n}$ sabit katsayıları Fourier katsayıları olarak adlandırılır. Denklemdeki $a_{n}$ ve $b_{n}$ katsayılarının tahmini ise:

$a_{m}=\frac{1}{\pi} \int_{-\pi}^{\pi} f(t) \cos (m t) d x$

$b_{m}=\frac{1}{\pi} \int_{-\pi}^{\pi} f(t) \sin (m t) d x$

şeklinde yapılmaktadır. Yukarıda verilen denklemden de anlaşılacağı üzere, Fourier serisi, sinüslerin ve kosinüslerin doğrusal bir bileşenidir. Ayrıca bu sinüs ve kosinüslerin her biri kendiliğinden frekansın fonksiyonudur. 